\title{
DAIIY PROGRAM
}

9TH INTERNATIONAL CONGRESS OF BIORHEOLOGY

AND

2ND INTERNATIONAL CONFERENCE ON CLINICAL HEMORHEOLOGY

Big Sky, Montana, USA

23-28 JULY 1995

\author{
23 July (Sunday) \\ 15:00-16:00 hrs \\ 16:30-17:30 hrs \\ Laboratory
}

24 July (Monday)

8:30-9:30

$10: 00-12: 30$

$12: 30-4: 30$

$15: 00-17: 40$
Opening Ceremony

Special Report: Guidelines for Clinical Trials and Methodology in Blood Rheology

Plenary Lecture by G. D. O. Lowe:

P1 Hemorheology and Cardiovascular Risk

Symposia:

S1 Ultrastructure of Endothelium and Leukocytes

S2 Red Blood Cell Lipid Bilayer and Shape Regulation

S3 Hemorheological Aspects of Myocardial Ischaemia

S4 Laser Diffraction Methods in Biorheology

Plenary Lecture by D. Hammer:

P2 Cell-Cell Adhesive Interactions

Symposia:

S5 Ultrasound and Hemorheology

S25A Biorheology in Cellular Interaction and Tissue Engineering

S7 Aggregation in Suspensions

S8 Small Volume Resuscitation and Hemodilation 
18:00-19:30

25 July (Tuesday)

07:00-08:30

08:30-09:30

10:00-12:30

$13: 30-14: 30$

15:00-17:00

$18: 00-19: 30$

27 July (Thursday)

07:00-08:30

08:30-09:30

$10: 00-12: 30$

$13: 30-14: 30$

$15: 00-16: 40$
Poster Viewing (F1-F110)

Poster Viewing (F1-F110)

Poiseuille Award Ceremony and Lecture

Symposia:

S9 Leukocyte-Endothelial Cell Interactions

S10 Heparin-induced LDL/fibrinogen Precipitation (H.E.L.P.)

S11 Microcircualtion and Rheological Factors during Ischemia

S12 Rheology of Hemolytic Anemias

Debate: Importance of Red Cell Aggregation in In-vivo Blood Flow.

Paul Johnson and Peter Gaehtgens

Symposia:

S13 Fibrinogen

S14 Fluid Shear Stress and Vascular Endothelial Cell Function

S15 Hemorheological Effects of Free Radicals and Oxidative Damage

S29 Synovial Fluid and Substitutes

Poster Viewing (F111-F205)

Poster Viewing (F111-F205)

Plenary Lecture by M. Kaibara:

P3 Rheology of Blood Coagulation

Symposia:

S17 In-vitro Effects of Red Blood Cell Aggregation

S18 Rheology and Transport in Thrombolysis

S19 Gene Activity and Molecular Regulation of Cell Behavior

S20A Viscoelasticity of Blood and Other Fluids

Plenary Lecture by Y. -C. Fung

P4 Rheology of Living Soft Tissue

Symposia: 
S21 Molecular Mechanisms of Abnormal Blood Cell Adhesion

S22 Fluid Flow in Bone and Cartilage

S23 Rheologic Factors in the Pathology of Vascular Disease

S20B Visoelasticity of Blood and Other Biofluids

17:00-18:00

18:00-19:30

28 July (Friday)

07:00-08:30

08:30-09:30

$10: 00-12: 30$

$13: 30-14: 30$

$15: 00-17: 00$
ISCH Business Meeting

Poster Viewing (F206-F316)

Poster Viewing (F206-F316)

Plenary Lecture by D. E. Brooks: P5 Current Models of Red Blood Cell Aggregation

Symposia:

S24 Comparative Mammalian Hemorheology

S6 White Blood Cell Mechanics and Motility

S26 Microcirculatory Correlates of Adhesion Molecules

S27 Cancer Cell Adhesion, Migration and Metastasis

Plenary Lecture by R. M. Hochmuth:

P6 White Blood Cell Mechanics

Symposia:

S28 Hemorheological and Biological Effects of Poloxamers and Other Surfactants

S16 Cerebral Ischemia

S30 Update on Mucolysis: Strategies to Improve Function by Altering Mucous Gel Structure

S25B Biorheology in Cellular Interaction and Tissue Engineering 